\title{
Stories about Climate Change in Political and Survey Discourse ${ }^{1}$
}

\author{
Øyvind Gjerstad and Kjersti Fløttum
}

\section{Introduction}

Narration as a fundamental activity practiced among human beings dates back from long before writing was invented, and spread throughout many different civilisations. Within cultural and literary studies, it underwent a renaissance through the work of the Russian folklorist and scholar Vladimir Propp, who analysed the basic plot components of Russian folk tales (published in Russia in 1928, translated into English in 1958, Morphology of the Folktale). Then, with the breakthrough of text linguistics, the narrative perspective entered forcefully into analyses of non-fictional texts (Wehrlich 1976, van Dijk 1980, Adam 1992). There have been many discussions about the number of components in the narrative structure, but there is currently a more or less clear consensus on the five-component schema: initial situation, complication, reaction, resolution, final situation. The narrative structure has also entered non-linguistic fields, such as psychology and political science, and more particularly into climate-change discourse, where even the Intergovernmental Panel on Climate Change (IPCC) has described its reports as "narratives."

With this as its backdrop, the present contribution discusses the notion of narrative and its relevance in the analysis of climate-change discourse within various genres, to show that despite their differences in both content and structure, there is a common climate change narrativity. The comparison involves two very distinct genres. The first, which

1 The authors would like to thank the external evaluator for her/his careful reading and valuable comments. 
is the major object of study in the present article, is the political speech, exemplified by French President François Hollande's prepared remarks at the climate-change conference (COP21) in Paris in late 2015. The second genre, which is included for comparative purposes, has not yet received a fixed label, but has been called "survey discourse" (Fløttum 2017). This corresponds to answers to open-ended questions in a survey undertaken by the Norwegian Citizen Panel in 2015, where respondents answered freely in their own words the following question: "Concerning climate change, what do you think should be done?" The differences between the two genres are manifold. Political speeches are carefully drafted by professionals and represent an institutional commitment. Survey discourse consists of open answers to specific questions, formulated by anonymous respondents who most often are not specialists in the field, and who in no way are bound by their statements. Despite these differences, our findings show how these texts comprise a plot, and how different characters (heroes, victims, villains) are integrated into the unfolding 'story', thereby reflecting the socially pervasive nature of narratives. Another central aim of this paper is to show the theoretical and empirical value of analysing how a given narrative relates to other narratives on the same topic, through markers of linguistic polyphony (Nølke et al. 2004).

\section{Theoretical framework}

The analysis is based on two theoretical approaches, which describe different linguistic and text structural phenomena. At the macro-level of the text, we employ Fløttum \& Gjerstad's narrative framework (2013 a, 2013 b, 2016), which is largely based on Adam's theory on the narrative text sequence (1992). At the micro-level of words and sentences, we identify and explore markers of linguistic polyphony (Nølke et al. 2004), which signal the presence of other voices than that of the speaker or author at the moment of utterance. Among such linguistic phenomena we find reported speech and negation. Our hypothesis is that climate-change narratives not only constitute stories on climate change, but that they also relate to other narratives, be it explicitly or implicitly.

In his text-linguistic approach, Adam (1992) identifies five components in the prototypical narrative sequence - initial situation, complication, (re)action, resolution and final situation - which together constitute a complete narrative arch coupled with stable situations at the beginning 
and end. As shown in previous research (Fløttum \& Gjerstad 2016), the dramatic and transformative nature of climate change lends itself to this kind of narrative structure, such as in the following example, constructed for illustrative purposes (Fløttum \& Gjerstad 2016, 5-6).

(1) 1. (Initial situation) $\mathrm{CO}_{2}$ emissions increased dramatically between 1990 and 2007.

2. (Complication) Global warming has caused serious problems in numerous regions.

3. (Reaction) The Un organized an international summit in Copenhagen in 2009 (COP15) to discuss action on climate change.

4. (Resolution) But the negotiating countries did not reach any binding agreement of measures to undertake.

5. (Final situation) Climate change constitutes a serious threat to the Planet, and those who have contributed least to the problems are the ones most vulnerable to the consequences.

In a political, and more broadly, societal context, a climate-change (cc) narrative is not formed independently of others but inevitably relates to them by echoing these past narratives, either through their content, or by more clearly confirming or challenging them through the use of specific linguistic markers. Such markers give rise to polyphony, or 'multivoicedness', as described by the Scandinavian Theory of Linguistic Polyphony ("ScaPoLine") (Nølke et al. 2004). For example, through the use of negations, the author or speaker can refute an opposing point of view (pov) without naming its source, such as in the following example from the 2013 "Summary for Policy Makers," published by Working Group 1 of the International Panel on Climate Change (IPCC):

(2) Sea level rise will not be uniform.

Through the use of not, the authors implicitly convey that someone has the erroneous point of view (pov) that 'sea level rise will be uniform' (Gjerstad and Fløttum forthcoming). It is up to the recipient to infer the identity of the individual or collective responsible for this refuted pov. In a narrative perspective, example (2) could be seen as a point of divergence 
between two versions of the complication phase of an otherwise shared CC narrative.

\section{From narrative sequences to climate-change narratives: Hollande at} COP 21

In section (3.1), we explore the narrative properties of President François Hollande's opening remarks to the Paris Conference, considering the difference in components between the initial and final situations. However, such a narrative not only comprises an internal structure but also relates to other texts on this vast issue. The question is how to seek out signs of this larger debate within the text. This is where the Scandinavian Theory of Linguistic Polyphony comes in. In section 3.2, we examine how linguistic polyphony can be viewed as the meeting point of competing narratives.

\subsection{Narratives in political speeches}

On 30 November 2015, French President François Hollande made the opening statement at the Leaders Event, which kicked off the $21^{\text {st }}$ Conference of the Parties of the UnfCCC (COP21). Building on the common narrative of climate change as a man-made disaster, the speech focused on COP 21 as the pivotal moment in the struggle to mitigate and adapt to its worst effects. In other words, COP21 is presented as a fork in the road. ${ }^{2}$ The various components of the narrative (see Figure 1), are illustrated through examples drawn from the address.

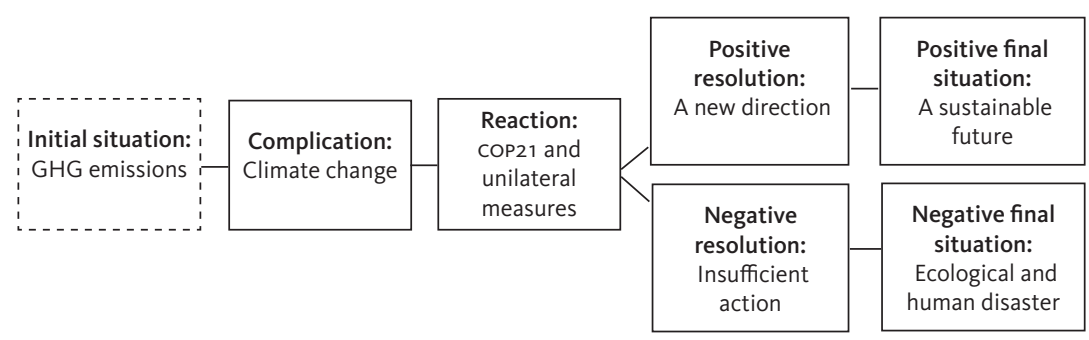

Figure 1: President Hollande's climate change narrative

2 See Gjerstad (2017) for analyses of other speeches at the same event, representing similar narrative structures. 
The initial situation remains largely implicit, as it constitutes a wellknown contextual backdrop for the problem at hand. It is only hinted at, for example, through two mentions of the word émissions and formulations such as "record de concentration de $\mathrm{CO}_{2}$ dans l'atmosphère" (see example (3)).

In contrast, the complication, i.e. climate change, is heavily elaborated upon, such as in example (3):

(3) 2015 a été l'année de tous les records : record de température, record de concentration de $\mathrm{CO}_{2}$ dans l'atmosphère, record du nombre d'évènements climatiques extrêmes, sécheresse, inondations, cyclones, fonte des glaces, hausse du niveau de la mer, acidification des océans. Les victimes de ces phénomènes se comptent par millions, et les dommages matériels par milliards. ${ }^{3}$

While this complication also constitutes commonly shared knowledge, the elaboration of this part of the narrative serves an argumentative purpose, in favour of the subsequent reaction. Furthermore, the secondary societal complications of climate change are also outlined:

(4) Le réchauffement annonce des conflits comme la nuée porte l'orage. ${ }^{4}$

In Hollande's story, the reaction phase starts in the build-up to COP21, when UNFCCC members were invited to announce their Intended Nationally Determined Contributions (INDC) for reductions in greenhouse gas emissions:

(5) 190 Etats ont formulé de plans d'action pour réduire les émissions de gaz à effet de serre et s'adapter aux dérèglements climatiques dans leur région respective. 5

3 "2015 has been the year of records: temperature record, highest $\mathrm{CO}_{2}$ concentration in the atmosphere, record number of extreme climate events, droughts, floods, cyclones, ice melting, rising seas, acidification of the oceans. The victims of these phenomena are in the millions, and the material damages in the billions."

4 "The warming brings forebodings of conflicts as the rain clouds bring the storm."

5 "190 states have formulated action plans to reduce greenhouse-gas emissions and adapt to climate disruptions in their respective regions." 
COP 21 constitutes the second part of the reaction component of the narrative, which, interestingly, contains no reference to previous international negotiations to curb cc. The conference is framed as the pivotal moment in the story:

(6) Votre présence soulève un immense espoir que nous n’avons pas le droit de décevoir. Car ce sont des peuples et des milliards d'êtres humains qui comptent sur nous.

[...] Nous sommes au bord d'un point de rupture. ${ }^{6}$

This opens up two future scenarios, depending on the success or failure of COP21. The positive scenario is represented by three conditions that form a resolution in the narrative:

a. design a trajectory to keep global warming under 2 degrees, or at least 1.5 degrees if possible;

b. a solidary response to $\mathrm{CC}$, which takes into account different levels of development and vulnerability

c. all societal actors need to get moving, including local leaders, investors, economic and social actors, and citizens.

Fulfilment of these three conditions would then lead to the final situation of the narrative:

(7) Cette transformation est à la fois une obligation morale et une opportunité mondiale. Elle ouvre des possibilités de développement grâce à l'émergence d'une économie décarbonée avec des énergies renouvelables, des modes de transport propre, le recyclage des déchets, l'agro écologie, la préservation de la biodiversité, l'accès de tous aux biens publics mondiaux?

6 "Your presence gives rise to enormous hope, which we do not have the right to disappoint, because populations and billions of human beings rely on us. [...] We are on the brink of a breaking point."

7 "This transformation is both a moral obligation and a global opportunity. It opens up development opportunities thanks to the emergence of a decarbonized economy with renewable energies, clean transportations, recycling of waste, agro-ecology, preservation of biodiversity, access to all common goods." 
Example (7) lists the properties of a future decarbonized economy, and is the only segment of President Hollande's speech which outlines a future final situation as the result of a comprehensive agreement in Paris ${ }^{8}$.

The negative scenario is less comprehensively described than the positive one, and is represented by only a couple of sentences, starting with the resolution:

(8) Le plus grand danger n'est pas que notre but soit trop élevé et que nous le manquions, mais qu'il soit trop bas et que nous l'atteignons. ${ }^{9}$

This potential fiasco is not accompanied by any extensive description of a negative final situation, other than what is often described as the most dramatic potential consequence of climate change: the disappearance of island nations:

(9) Je pense à ces îles qui peuvent à brève échéance purement et simplement disparaître. ${ }^{10}$

With regard to the characters involved in Hollande's narrative, there are heroes, villains and victims. The heroes are many, constituting a large group, and this serves to stress that the fight against climate change is a common global cause:

(10) Les collectivités locales, les entreprises, les investisseurs, les citoyens, toutes les grandes religions, se sont engagés pour le climat. ${ }^{11}$

At the level of governments, the 190 states which committed to the INDCs (see example 5) are also cast as heroes, with France and its Foreign Minister Laurent Fabius being singled out:

8 For an example of a more comprehensive final situation in the same context, see US President Barack Obama's remarks at the Leaders Event (Gjerstad 2017).

9 "The greatest danger is not that our goal is too high and that we miss it, but that it is too low and that we reach it."

10 "I'm thinking of the islands that can very soon quite simply disappear."

11 "Local communities, businesses, investors, citizens, all the major religions, have enlisted in the climate effort." 
(11) La France a jeté toutes ses forces dans ce combat, et mobilisé l'ensemble de son gouvernement, à commencer par le Ministre des Affaires étrangères Laurent Fabius, dont je veux ici saluer la ténacité. ${ }^{12}$

Hollande also dramatizes the efforts by another group of heroes:

(12) Je rends hommage ici à tous les pionniers de la cause écologique, aux précurseurs qui, il n'y a pas si longtemps encore, devaient affronter incrédulité et dédain pour leurs alertes et leurs propositions. ${ }^{13}$

Example (12) echoes the Cassandra syndrome which is often associated with environmentalists, thus creating a sub-plot of tragedy around this group of heroes. This effect is emphasized by the use of the word alerte, which echoes the expression lanceur d'alerte, frequently used in the French public debate on climate change.

With regard to other characters, there are few concrete villains to be found, which corresponds with other analyses of government discourse (see Fløttum \& Gjerstad 2013a, 2013b, Fløttum \& Espeland 2014). In an international diplomatic context where the aim is to achieve global consensus, very little can be gained by singling out actors that are to blame for negative developments. This is reflected in the fact that the villain appears only in the form of the pronoun nous (we) and its corresponding determiner nos (our), such as example (13):

(13) Nous ne pouvons plus considérer la nature comme un vulgaire et inépuisable réservoir de ressources destiné à notre seul accomplissement. ${ }^{14}$

The use of the pronoun nous serves to mitigate any affront to the audience, as it includes both the speaker and an indefinite collection of other actors.

The victims of the story are the poor countries of the world:

12 "France has thrown all its strength into this battle, and has mobilized the whole government, notably the Foreign Minister Laurent Fabius, whose tenacity I salute."

13 "I pay tribute to all the pioneers of the environmental cause, to the forerunners who, not that long ago, had to face disbelief and disdain for their warnings and their proposals."

14 "We can no longer consider nature as a common and inexhaustible reservoir of resources uniquely reserved for our self-fulfillment." 
(14) [C]omment accepter que ce soit les pays les plus pauvres, ceux qui émettent le moins de gaz à effet de serre qui soient les plus vulnérables. C'est donc au nom de la justice climatique, que nous devons agir. ${ }^{15}$

The discrepancy in historical responsibilities for GHG emissions and vulnerability to their consequences is a common topic in discourse on $\mathrm{CC}$, and also constitutes an important point for negotiation within the UNFCCC (see Gjerstad 2017).

In general, Hollande's speech develops a climate change policy narrative which, in its fundamental structure (see figure 1) and its cast of characters, resembles that of other policy texts on the issue (see Fløttum \& Gjerstad 2013a, 2013b, Fløttum \& Espeland 2014, Gjerstad 2017). There is widespread agreement on the causes and consequences of climate change and the need to deal with the problem through collective and international efforts, as well as on the prospect of dramatically different outcomes in case of success or failure. However, within this commonly shared framework, there are differences. On a global issue involving diverging opinions and interests, the debate also comprises conflicting voices, and authors and speakers feel compelled to handle these voices in different ways, by for example refuting them or aligning with them. The manner in which this is done plays an important part in building support for policies and alliances among key actors. Furthermore, by including such voices in Cc policy texts, the author or speaker also opens a window into alternate narratives, which may or may not be accurately portrayed. Analysing the polyphony of such texts, therefore, provides the opportunity to investigate how authors or speakers place themselves in the ecosystem of narratives that exist on a given policy issue. In the following, we explore the polyphonic interpretation of various linguistic markers that appear in President Hollande's remarks.

\subsection{The meeting of narratives through linguistic polyphony.}

Interestingly, there is no reported speech, which means that the President does not explicitly give the floor to other voices. However, the analysis of

15 "How can we accept that the poorest countries, those that emit the least greenhouse gases, are the ones that are the most vulnerable. It is therefore in the name of climate justice that we need to act." 
more subtle markers such as negation and concessive connectives (e.g. mais (but)) reveals that these voices are far from absent. In the following, we consider three cases of negation which constitute meeting points between CC narratives in the speech:

(15) Nous sommes en ce premier jour de la cop au pied du mur. Ce mur est l'addition de nos égoïsmes, de nos appréhensions, de nos résignations. Il est construit sur l'indifférence, sur l'insouciance, sur l'impuissance. Il n'est pas infranchissable. Tout dépend de nous. ${ }^{16}$

The negation here gives rise to an underlying point of view (pov), which the speaker refutes, without divulging the identity of the voice behind this pov (Nølke et al. 2004):

Pov $_{1}$ : The wall is insurmountable.

$\mathrm{Pov}_{2}$ (speaker): Pov1 is erroneous.

Going back to Figure 1, the sentence "It is not insurmountable" relates to the possibility to transition from the reaction to the positive resolution of the CC narrative, and pov ${ }_{1}$ expresses the impossibility of this transition, as illustrated in Figure 2:

Hollande's version:

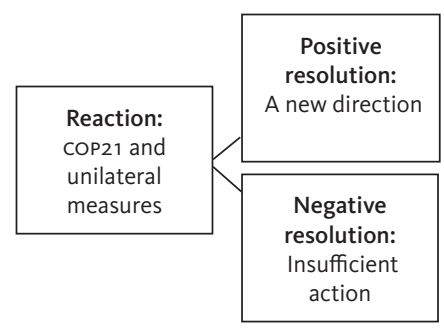

16 "On the first day of the cop, we are up against the wall. This wall is the sum of our egoisms, our apprehensions, our resignations. It is built on indifference, on insouciance, on helplessness. It is not insurmountable. Everything depends on us." 
Refuted version:

\begin{tabular}{|l|l|}
\hline $\begin{array}{l}\text { Reaction: } \\
\text { COP21 and } \\
\text { unilateral } \\
\text { measures }\end{array}$ & $\begin{array}{c}\text { Negative } \\
\text { resolution: } \\
\text { Insufficient } \\
\text { action }\end{array}$ \\
\hline
\end{tabular}

Figure 2: Arguing against fatalism

Hollande refutes the point of view that there is only one possible, negative, resolution, which could be attributed to a collective voice representing the fatalism which has been growing in the face of insufficient agreement at previous cops. Such an attitude threatens to be self-fulfilling if not counteracted. Thus, the negation could be interpreted as a preemptive move by the French President.

The following negation represents conflicting views regarding the final situation of the narrative:

(16) Le plus grand danger n'est pas que notre but soit trop élevé et que nous le manquions, mais qu'il soit trop bas et que nous l'atteignons. ${ }^{17}$

As in example (15), the negation signals a confrontation between two povs:

Pov: The biggest danger is that our goal is too high and that we miss it.

$\operatorname{Pov}_{2}$ (speaker): Pov $_{1}$ is erroneous.

After negating pov, the speaker clarifies his position by offering an alternative, through the adversative but: 'the biggest danger is that our goal is too low and that we reach it'.

Thus, there are two versions of a negative final situation, in spite of a positive outcome of the Paris negotiations:

17 "The biggest danger is not that our goal is too high and that we miss it, but that it is too low and that we reach it." 
Rejected version:

\begin{tabular}{|c|c|}
\hline $\begin{array}{c}\text { Positive } \\
\text { resolution: }\end{array}$ & $\begin{array}{c}\text { Negative final } \\
\text { s new direction } \\
\text { sot reaching a goal } \\
\text { which is too high }\end{array}$ \\
\hline
\end{tabular}

Hollande's version:

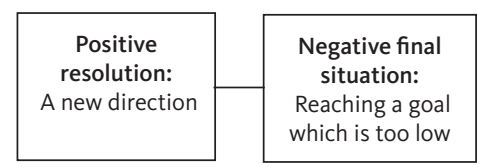

Figure 3: Competing final situations

The last example of a negation that serves to confront an opposing narrative also includes the concessive connective mais (but):

(17) Je mesure combien combiner l'impératif de l'urgence et les choix du long terme est un exercice difficile. Mais il n'est pas impossible. ${ }^{18}$

The negation gives rise to a pov that is refuted by the speaker: 'combining the imperative of urgency with long-term choices is impossible', echoing the fatalist voice in example (16). Furthermore, the concessive structure $X$ but $Y$ lets the speaker admit to an argument (i), while presenting a counter-argument (ii) as more relevant for the issue at hand. The two arguments are in indirect opposition to each-other, since they are oriented towards opposing implicit conclusions. In light of the situational context, it would seem plausible that these conclusions concern the level of ambition to bring to the negotiations at COP21:

(i) I realize that combining the imperative of urgency with longterm choices is a difficult exercise. $\rightarrow$ We should aim low.

(ii) It is not impossible. $\rightarrow$ We should aim high.

In narrative terms, this leads to two competing resolutions:

18 "I realize that combining the imperative of urgency with long-term choices is a difficult exercise. But it is not impossible." 
Rejected version:

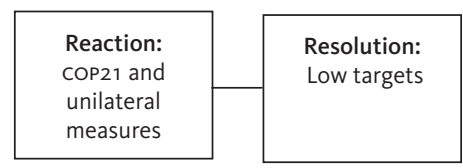

Hollande's version:

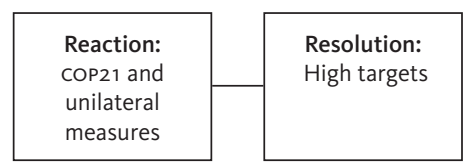

Figure 4: Competing resolutions

Throughout Hollande's confrontation with alternative Cc narratives, the point of contention is not the existence of man-made CC, or the attribution of blame, but rather the level of ambition going into the negotiations. The French President presents himself as pushing for stronger measures, in contrast to less ambitious (and unnamed) negotiation partners. Thus, the speech has a consensus-oriented and motivational tone, in keeping with France's role as host.

\section{CC Narratives in Survey Discourse}

Having explored the polyphonic properties of CC narratives in a political speech, the question is whether survey answers on the same issue display the same narrative properties, and if so, whether there are polyphonic markers that serve as meeting points between narratives. Given the noncommittal nature of statements given during such surveys, building and maintaining consensus has no interactional value. In addition, the issue itself is characterized by an array of competing interests and opinions, on a global scale. We hypothesize, therefore, that linguistic polyphony occurs at all stages of cc narratives in survey answers, depending on the respondent's view on $\mathrm{cc}$, both as a natural phenomenon and as a policy issue.

In the two survey rounds (spring and autumn 2015) of the Norwegian Citizen Panel, respondents were asked the following question: Concerning climate change, what do you think should be done? 
This question contributes to the construction of the cc narrative, firstly by mentioning and thereby imposing the complication ("climate change") on the respondents, and secondly by focusing the respondents' attention on the reaction ("what do you think should be done"). Furthermore, the necessity of this reaction is presupposed by the question, which implies 'something should be done'. In a polyphonic perspective, a presupposition is semantic content that is taken for granted by the speaker and is exempt from discussion, and is therefore also presented as accepted by the recipient (Nølke et al. 2004). In an interactional perspective, such an imposition of consensus can be problematic if the recipient does not agree with the presupposed content. This is reflected in some of the answers:

(18) Bare tull! Verden har forandret seg i millioner av år!!19

In example (18), the respondent directly challenges the existential presupposition of CC:

Pov $_{1}$ : 'there is man-made climate change'

$\mathrm{Pov}_{2}$ : 'Pov 1 is nonsense'

By refuting pov, the respondent not only indicates disagreement with the fundamental premise of the question, but also dismantles the entire CC narrative by blocking the complication, and thereby removing the possibility of any further development in the form of reaction, resolution and final situation.

With regard to the answers that accept the presupposition of climate change and the need to act, many are brief, consisting of only sentence fragments in the form of noun phrases (19) or infinitive constructions (20), which reflects the spontaneous and often hurried nature of such survey answers:

(19) Høyere avgifter på klimautslipp. Prioritet på klimavennlig transport. ${ }^{20}$

(20) Begrense forurensningen av biler i nærmiljøet. Lære ungdommen å ikke kaste søppel der de finner det for godt. Ta vare på regnskogen. ${ }^{21}$

19 "All nonsense! The world has been changing for millions of years!"

20 "Higher taxes on climate emissions. Priority for climate friendly transportation."

21 "Limit car pollution in the local environment. Teach young people not to litter wherever they please. Take care of the rain forest." 
These succinct lists directly answer the question, with no further elaboration or argumentation. Thus, the CC narrative is cut short, remaining embryonic in its lack of resolution, although details may be added to the narrative, concerning villains and causes to the problem. Nevertheless, many answers did enter into discussions on the question of what to do about climate change:

(21) Få industrien til å forstå for eksempel at det å sende fisken med fly til Østen for å få den renset, og så tilbake igjen, er GALEMATIAS, nemlig at industrien produserer helt unødig utslipp fra fly. ${ }^{22}$

In example (21), the respondent suggests that the reaction component of the narrative should be to change the behaviour of the manufacturing industry, which is portrayed as a villain using value-laden and emotional terms, through the use of the noun GALEMATIAS (lunacy) written in capitals. The utterance is polyphonic, as it outlines a possible future common point of view: 'sending fish by air to the East to get it cleaned, and then back again, is lunacy'. This pov is at the centre of the resolution of the narrative:

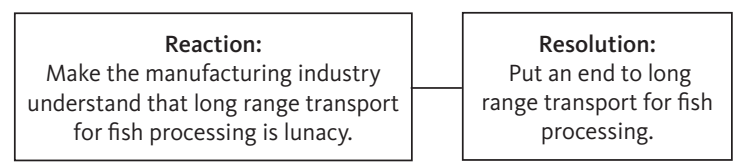

Figure 5: Converting the villain

The next example comprises a concessive connective, which gives rise to different povs and diverging narratives:

(22) Norge er allerede et land som tar klima på alvor og det skal vi fortsette med, men vi bør hjelpe andre land som utgjør en større risiko for klimaet enn hva Norge gjør. ${ }^{23}$

22 "Make the manufacturing industry understand that, for example, sending the fish by air to the East to be cleaned, and then back again, is LUNACY; namely, the industry is producing completely unnecessary emissions from planes."

23 "Norway is already a country that takes the climate seriously, and we must continue to do so, but we should help other countries that pose a greater risk to the climate than Norway." 
As analysed in example (17), the counter-argumentative connective but allows the speaker or author to acknowledge a point of view (i), without accepting the conclusion which might be drawn from it, by offering a counter-argument (ii):

(i) Norway is already a country that takes the climate seriously, and we must continue to do so $\rightarrow$ Norway is already making all necessary efforts (implicit)

(ii) We should help other countries that pose a greater risk to the climate than Norway $\rightarrow$ Norway is not making all necessary efforts (implicit)

The indirect opposition between (i) and (ii) constitutes a point of divergence between two narratives:

\section{Diverging narrative:}

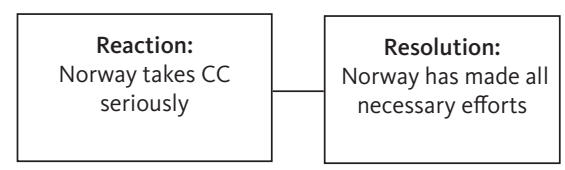

Respondent's narrative:

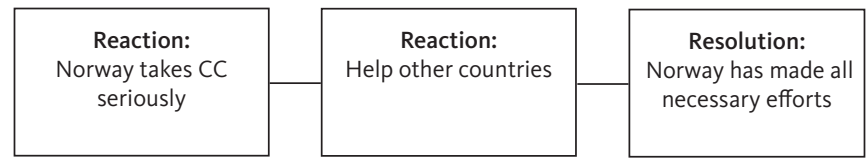

Figure 6: Diverging narratives through concession

As is to be expected from a nation-wide survey, the variety of answers is great, in terms of both length and syntactic structure. The societal salience of the climate issue is also reflected in the range of polyphonic markers used, which serve as meeting points between converging and diverging narratives. The expressive freedom of the anonymous surveys also gives rise to a large variety of $\mathrm{CC}$ narratives, despite the restricting effect of the survey question. The answers address a wide array of topics, such as public transport, energy transition, consumption and the international dimension. A few go so far as to deny the problem of CC alto- 
gether, thereby challenging the presupposition of the question itself, and dismantling the entire narrative. ${ }^{24}$

\section{Discussion and Conclusion}

Comparing François Hollande's remarks at COP21 and the survey answers from the Norwegian Citizen's panel, there are clear similarities, despite the obvious linguistic and text-structural differences. At the level of narrative structure, the same components are often to be found or tacitly taken for granted: human $\mathrm{CO}_{2}$ emissions are causing climate change, a problem which needs to be dealt with through local, national and international efforts. These similarities indicate that the general story of climate change is largely shared across cultures. Furthermore, at a theoretical level, our analysis shows that the narrative framework is applicable to very different genres. In the present case, one of these is characterized by high stakes and meticulous preparation, the other by low stakes and spontaneous expression. Lastly, the combined narrative and polyphonic analysis can serve to highlight the fact that a narrative is not only a "story" in its own right, but that it also derives its situational and societal relevance from its interaction with other narratives, traces of which can be found in the form of polyphonic markers. Thus, the narrative-polyphonic analysis of survey responses on issues such as climate change could identify societally dominant narratives by investigating their traces in these responses. Thus, the mainly theoretical findings of the present paper constitute a point of departure for future research on this empirical question.

\section{References}

Adam Jean-Michel. 1992. Les textes: types et prototypes. Paris: Nathan.

Fløttum, Kjersti. 2017. "Willingness to Action." In The Role of Language in the Climate Change Debate, edited by Kjersti Fløttum, 113-29. New York/London: Routledge.

Fløttum, Kjersti, and Tonje J. Espeland. 2014. "Norske klimanarrativerhvor mange 'fortellinger'? En lingvistisk og diskursiv analyse av to norske stortingsmeldinger." Sakprosa 6 (4):1-18.

Fløttum, Kjersti, and Øyvind Gjerstad. 2013a. "Arguing for Climate Policy through the Linguistic Construction of Narratives and Voices: The

24 For more on the topics in the survey answers, see Tvinnereim et al. (2017). 
Case of the South-African Green Paper 'National Climate Change Response." Climatic Change 118:417-30.

Fløttum, Kjersti, and Øyvind Gjerstad. 2013b. "The Role of Social Justice and Poverty in South Africa's National Climate Change Response White Paper." SJHR 29 (1):61-9o.

Fløttum, Kjersti, and Øyvind Gjerstad. 2016. "Narratives in Climate Change Discourse." Wiley Interdisciplinary Reviews: Climate Change, doi:10.1002/wcc.429 (accessed 9 January, 2017).

Gjerstad, Øyvind. 2017. "Competing Climate Change Narratives: An Analysis of Leader Statements During COP21 in Paris." In The Role of Language in the Climate Change Debate, edited by Kjersti Fløttum, 31-48. New York/London: Routledge.

Gjerstad, Øyvind, and Kjersti Fløttum. (forthcoming). "From Refutation to Description: Negation as a Rhetorical Tool in Climate Change Discourse." In Pragmatics of Negation, edited by Malin Roitman. Amsterdam: John Benjamins.

Nølke, Henning, Kjersti Fløttum, and Coco Norén. 2004. ScaPoLine: la théorie scandinave de la polyphonie linguistique. Paris: Kimé.

Propp, Vladimir. 1958. Morphology of the Folktale. Austin, TX: University of Texas Press.

Tvinnereim, Endre, Kjersti Fløttum, Øyvind Gjerstad, M.P. Johannesson, and Åsta D. Nordø. 2017. “Citizens' Preferences for Tackling Climate Change: Quantitative and Qualitative Analyses of their Freely Formulated Solutions." Global Environmental Change 46: 34-41.

Van Dijk, Teun A. 1980. Macrostructures. Hillsdale, NJ: Lawrence Erlbaum Associates.

Werlich Egon. 1976. A Text Grammar of English. Heidelberg: Quelle and Meyer. 